\title{
Technical Writing in French in Canada: Results of Two Surveys
}

\author{
Pamela Russell and Hélène Cajolet-Laganière \\ Université de Sherbrooke \\ Jacqueline Bossé-Andrieu \\ University of Ottawa
}

Most North American research into technical writing explores the profession as it is practised in English; investigation of technical writing in languages other than English centres mainly on technical translation. This paper points out that in Canada, and primarily in Quebec, there is a considerable body of technical documentation written originally in French. Through an analysis of two surveys conducted by the authors it attempts to identify who these French-language professional and technical writers are, where and under what conditions they work, and what type of training they have.

SINCE THE BEGINNING OF THE 1970s, the field of technical writing has been growing by leaps and bounds in both the United States and Canada. The profession of technical writing has been the object of numerous studies; one need only look at the works of Moran and Journet (1985) and Hull (1987) to appreciate the extent of the documentation on the field and the profession. Moreover, a number of American journals (IEEE Transactions on Professional Communication, Journal of Technical Writing and Communication, Technical Communication Quarterly, Journal of Business and Technical Communication, etc.) as well as the Canadian journal Technostyle regularly publish articles devoted to technical writing.

Much of what is written about technical writing in the United States applies to the profession in Canada. Thus, within these publications, little distinction is made between technical writing in these two countries, and Canadian researchers' articles are frequently published alongside those of their American colleagues. Yet the vast majority of these publications explore the profession of technical writing only as it is practised in English. Issues 
related to technical writing in languages other than English are addressed mainly within the context of technical translation.

Certainly, the majority of technical documents produced in Canada, other than in Quebec, are written originally in English, and the predominant interest in English-language technical writing is a reflection of this fact. Many of these documents are subsequently translated into French if the federal government's official language legislation so requires, or if they are intended for readers in Quebec. As a result, interest in the field of technical writing in Canada naturally includes the issue of translation. Seguinot points out that the roles of technical writers and translators are overlapping more and more (285).

Not all Canadian technical documents are, however, written originally in English. There is a considerable body of technical documentation written originally in French in Canada, mostly in Quebec. The French presence is becoming more visible in the field: In the past year, the profession has been explored by Larivière and by the authors of the present article (BosséAndrieu, Cajolet-Laganière and Russell) and a number of well-known French textbooks on business and technical writing have been published in Quebec (for example, those of Cajolet-Laganière et al., Clas and Horguelin, and Larose) as well as in Europe (for example, those of Marret et al., TimbalDuclaux, and Kocourek). As well, the Montreal Chapter of the Society of Technical Communicators (STC) has established a French interest group; a Quebec professional writers' association called the Sociêté québécoise de rédaction professionnelle has been formed; and French participation and representation in the Canadian Association of Teachers of Technical Writing has been active though small since the association's inception.

Who are these French-language technical writers? Where do they work, and under what conditions? What type of training do they have? In order to learn more about this little-known group, we conducted two separate surveys of French-language professional and technical writing in Canada.

\section{Linguistic Context}

In order to understand the reality of French-language technical writing in Canada and to understand how it differs from technical writing in English, one must consider the linguistic context in which this writing is done. For the writer's work and the workplace itself are significantly affected by linguistic as well as social, political and geographical factors. Canada is not only an officially bilingual country, but also a federation of two territories 
and ten provinces, only one of which has French as its sole official language. Quebec has a population of approximately six million francophones and 900,000 anglophones. In addition, almost two million francophone Canadians live in other provinces, where they are a linguistic minority.

Since at the federal level Canada has two official languages, both English-speaking and French-speaking Canadians are accorded the same rights and privileges, and federal government services are provided in both French and English. All official publications of the federal government are produced in both languages. Parliament and federal courts operate in the two official languages, and the Canadian Broadcasting Corporation provides programming in both French and English. As well, regulations governing the packaging and labelling of consumer products require that both official languages be used. All of these factors contribute to the need for a large quantity of texts to be produced in both English and French.

On the provincial level, the situation is complex. English is the official language of most provinces. New Brunswick, however, with 240,000 francophones, is officially bilingual, and Ontario, with 500,000 francophones, provides French services within government agencies and in some offices that serve French-speaking communities. In Quebec, however, French has been the sole official language of the province since the Charte de la langue française (Bill 101) was passed in 1977. French is thus the dominant language of the courts, administration, legislation, workplace, business, and education. Nevertheless, although French is the official language, Quebec is part of a bilingual country, located on a largely Englishspeaking continent.

This complex linguistic situation shapes the practice of Frenchlanguage professional and technical writing in Canada. Federal government publications and services are bilingual; Quebec publications and services are largely unilingual; and the business community in both Canada and Quebec must deal with the realities of official bilingualism, a Frenchspeaking Quebec market, a bilingual Canadian market, as well as North American and world markets in which English plays a dominant role. All of these factors affect the practice of professional and technical writing in French in Canada, and the profile of the French-language writer.

\section{The Study}

The purpose of the study described in this article was to define the profession of French-language technical writing. To this end, the researchers 
involved in this investigation - three university professors who teach professional writing at the University of Ottawa and the Université de Sherbrooke - conducted two surveys. The first survey targeted professional writers themselves - language specialists who write for a living. When we examined the results of this first survey, we realized that professional writing, and in particular technical writing, is frequently done by a group of people we had not yet contacted - subject-matter specialists who, although employed as engineers, technicians, or the like, spend much of their time writing. As a complement to our first survey, we thus conducted a second inquiry focused on subject-matter specialists who produce written documents in French. The findings from these two surveys are presented below.

\section{The First Survey}

We conducted our first survey in 1994, with the intention of defining French-language professional writing in Canada and situating technical writing within this profession. Our goals were to determine who Frenchlanguage professional and technical writers were, who their employers were, what type of work they did, and what their educational background was; as well, we wanted to explore the employers' perceptions of the profession.

We drew up a questionnaire which inquired about the work of the writer, the documentation and computer tools used on the job, the training and recruiting of writers, and the employers' expectations. Although we targeted French writers, we asked them about the role English played in their work: we wanted to determine whether or not their work included translation, writing in English, or consulting English-language documentation. In our attempt to define the profession, we chose to target the broader category of professional writer and to include within our questionnaire a section designed specifically for technical writers.

We sent our questionnaire to more than 600 potential respondents. About two-thirds of the questionnaires went to private enterprise: we targeted the francization ${ }^{1}$ services of large Quebec companies representative of a variety of fields (communications, pulp and paper, insurance, publishing, mining, manufacturing, high technology, etc.) as well as a selection of small and medium-sized businesses. We also included businesses that employ

1. Under its francization policy, the Quebec government's Office de la langue française requires Quebec companies to establish internal services to ensure and promote the use of French. 
technical writers from the Montreal branch of the STC and companies that employ student writers in the Université de Sherbrooke's cooperative system. As well, we sent questionnaires to federal and provincial government services (located in Ottawa-Hull, Montreal, Quebec City and Toronto), specifically targeting those services that are responsible for writing, publishing, or communications. Finally, we included in our survey a number of free-lance writers who advertise their French-language services in telephone directories or who were listed as French writers in the directories of the Association of Translators and Interpreters of Ontario and the Société des traducteurs du Québec (now known as the Ordre des traducteurs et interprètes agréés du Québec).

Of the 634 questionnaires sent out, 120 were completed and returned. We eliminated 8 of these from the study, since the respondents indicated that they did no writing (as opposed to translation) in French. Of the remaining 112 questionnaires, which form the basis of this first survey, 60 were received from private enterprise (58 companies in Quebec and 2 in Ontario), 11 from the Quebec provincial government, 36 from Canadian federal government services located both within and outside Quebec, and 5 from free-lancers ( 3 in Quebec and 2 in Ontario). We realize that our sample is not representative of all of Canada; however, since the vast majority of documents written originally in French are produced either within Quebec or within the federal government, our data appears to be relatively proportional to the jobs available in the field. Owing in part to the numerous comments, explanations, and details the respondents included to supplement the information that we specifically asked for, we were able to establish a profile of the French-language professional writer.

\section{The Profile of the Professional Writer}

The most striking observation to emerge from the analysis of our data was this: French-language professional writing in Canada is far from homogeneous, and is practised under very different circumstances, depending on whether the writer works for private enterprise, for the federal government, for the Quebec provincial government, or on a free-lance basis. These differences are related to the type of work that the writer does and the role that English plays in this work.

In the Quebec government, writing only in French accounts for almost one half (46.4\%) of the work French writers do; editing, summarizing, and lay-out account for most of the remaining work. Less than $1 \%$ of the writers' 
work involves translation, adapting English-language texts, or writing in both languages. In contrast, in the federal government, writing only in French accounts for approximately one-quarter $(25.8 \%)$ of the French writers' workload, whereas translating, adapting English-language texts, and writing in both languages account for almost one-third $(31.1 \%)$, with editing also being a fairly important component. In private enterprise, almost onethird (32.5\%) of the French writers' work consists of writing in French only, with writers doing more translation than in either of the previous two groups, but less writing in both languages. Freelancers report a very different breakdown of their work: translation accounts for almost half their workload (44.3\%), with writing in French accounting for only $7 \%$.

The relative proportions of writing and translation done by these writers can be explained by the linguistic context in which they work. It is not surprising that a writer employed by the bilingual federal government is more likely to be required to translate or work in English as well as in French, whereas a writer working for the Quebec government works virtually exclusively in French. French writers in the private sector and free-lancers reflect in their work the reality of the marketplace, doing translation as well as original writing.

Another factor that was directly related to the type of work done was the degree of specialization of the texts the writer worked with. Quite a few of our respondents pointed out that highly specialized texts, particularly in the field of high technology, are often conceived in English and then translated into French. Highly specialized texts that are conceived and written originally in French are frequently produced by subject specialists rather than by professional writers.

\section{Fields of Specialization}

In our attempt to define professional writing, we asked a series of questions concerning the fields of specialization in which the writers worked. Figure 1 shows the major fields reported. Our analysis revealed that administrative writing was the most frequently identified category, with more than $70 \%$ of the writers indicating that they worked in this field. The figure was particularly high in the public sector, but administrative writing was also the leading category in the private sector.

The second most commonly identified field was that of technical writing, with $68 \%$ of respondents indicating that they worked in the technical field. The figure was considerably higher in the private sector than in the 
public sector. Here again, the comments made by the respondents were particularly informative: a number of the writers explained that highly specialized technical texts were sent out to subject specialists (engineers, computer scientists, etc.), whereas the professional writers themselves dealt with the less specialized material. Indeed, it was this observation that led us to undertake our second survey, described later in this article, in which we explored the role of the subject specialist as writer.

By isolating the responses of those writers who indicated that they work with technical texts, we were able to establish a subgroup of respondents that we could identify as French "technical writers." However, when we compared the data obtained from this subgroup with the data obtained from the entire population of "professional writers" surveyed, there was no significant difference between the figures. The general observations that we make about "professional writers" thus can also be applied to this subgroup of "technical writers."

To learn more about the technical writing produced by our respondents, we included a section specifically on this subject. The respondents specified that the technical texts they produced included manuals, estimates, calls for tenders, reports, standards, specifications and procedures, and of course, correspondence related to the technical field. We were particularly interested in the roles of French and English in the production of the technical documents, and the breakdown of responses by employers brought to light

Figure 1: Major Fields in Which Professional Writers Work

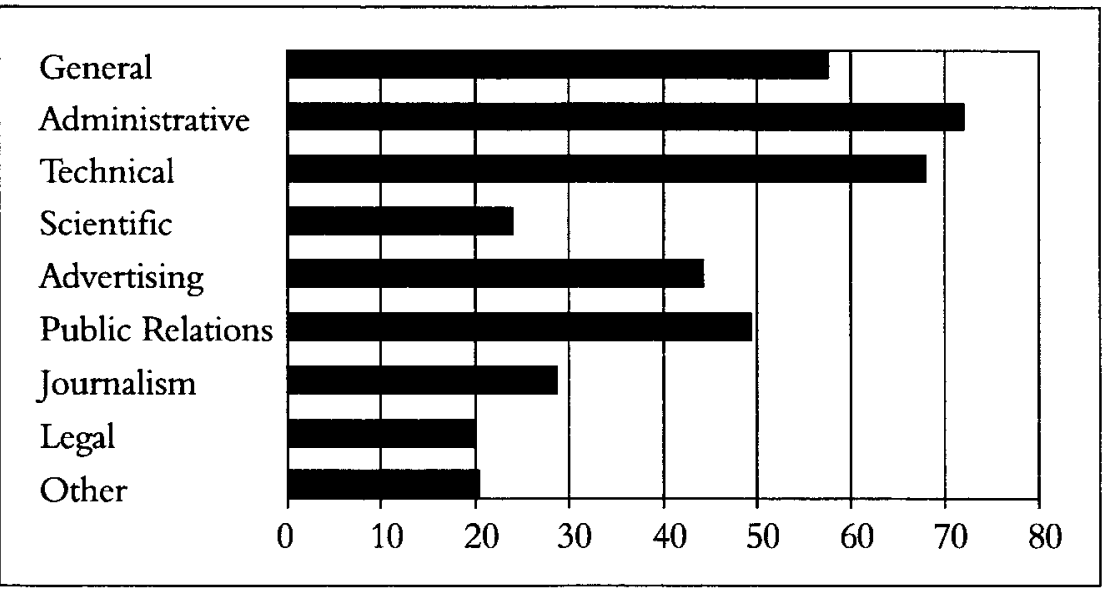


some striking differences.

More than $90 \%$ of technical texts produced by writers working for the Quebec government were conceived and written in French. (Even in the technical field, the Quebec government is successful in promoting the production of original French-language material.) This figure fell to less than $60 \%$ for technical texts produced in the private sector, and to approximately $40 \%$ for those produced in the federal government. Again, the free-lancers reported a very low proportion of texts written originally in French, with most of their texts being produced either by translation or by adaptation of English texts. The results reflect the linguistic and political reality in which the writers work.

This same distribution was reflected in the answers to our questions concerning the documentation that the writers use and consult. In the Quebec public service, writers usually work with French-language documentation, although some use of English-language documentation was reported. In both the federal public service and in the private sector, the situation was quite different: French-language writers use both English and French documentation extensively, and in some cases, they use exclusively English documentation.

\section{Employers' Requirements}

We included in our questionnaire a section intended specifically for employers, in which we asked questions about the type of education, training, abilities and skills the employers look for when hiring writers.

The great majority of the employers require that a professional writer have a university degree; however, the type of degree varies considerably. Approximately $22 \%$ of employers specified a BA in professional writing in French; however, this figure no doubt is influenced by the fact that a number of the employers in our sample were participants in the Universite de Sherbrooke's cooperative program, wherein they employ students who are working towards this very degree. The next most commonly mentioned degrees were a BA in French or a BA in translation (private sector employers in particular valued the degree in translation). For almost one third of the . employers, however, the type of degree mentioned varied greatly - a BA in administration, economics, communications, advertising, journalism, or a $\mathrm{BSc}$, or in some cases, a Master's degree. Almost half of the employers have additional requirements: for example, many require previous work experience, and some, particularly in the federal government and in the 
private sector, require that a candidate be bilingual.

Moreover, forty percent of employers indicated that they have potential employees take a test. The test usually consists of writing a letter or article, editing or proofreading a text, or, in some cases, translating a text or revising a translation.

Employers were asked to rank the qualities and abilities they look for in professional writers. In descending order of importance, the qualities were ranked as follows:

1. knowledge of the language;

2. ability to write for a specific audience;

3. ability to write under pressure;

4. knowledge of a specialized field (particularly important in the private sector);

5. general knowledge;

6. creativity;

7. oral expression (again important in the private sector); and

8. computer skills.

Surprisingly, computer skills were ranked low on the list; yet virtually all the writers themselves reported that they used computers (IBM or compatible in $80 \%$ of the cases) in their work. Once again, comments made by the respondents were highly informative: employers specified that they look for people with tact, analytical skills, a critical mind, and the ability to adapt and to work in a team.

Respondents also made the distinction between writers and subject specialists. Employers indicated that when they hire writers, they are looking for language specialists, for communicators. They indicated that highly technical texts are most often written by subject specialists. Thus one organization may use two different types of writers, with very specialized texts being handled by the subject specialists, and less specialized texts (for example, correspondence, promotional and public relations texts, and company newsletters and reports) being produced by professional writers working in the company's communications or public relations office. As mentioned previously, this observation led us to undertake our second survey.

\section{The Second Survey}

In order to complete the picture of the professional and more specifically the technical writer who works in French in Canada, we 
undertook a second survey in 1995. This second survey had a narrower focus than the first one: we decided to look specifically at technical writing, and we targeted subject specialists who produce technical texts. Our subjects were not professional writers, but rather were specialists who write as part of their jobs.

We chose a considerably smaller sample for this second survey, and we drew up a new questionnaire adapted to our new target group. We sent questionnaires to 45 specialists working for the Quebec provincial government, for various specialized public services, and for the private sector. We received and analysed 21 responses: five came from private consulting firms, five from Quebec government services, six from transportation and other public services, three from construction companies, and two from the manufacturing sector. All respondents work in Quebec. With such a small sample, the data obtained are not statistically significant; nevertheless, they provide a useful complement of information to our first study.

The specialists who completed the questionnaires had a variety of types of university degrees: Bachelor's degrees and in some cases Master's degrees in fields such as engineering, environmental studies, urban planning, economics, and administration. On average, these subject specialists spend 15 hours a week actually writing; six of them spend between 20 and 30 hours a week writing. As well, they are involved in all stages of the preparation of documents - planning the text, writing the first draft, frequently editing the text, and also frequently being involved with layout, design and graphics. The large majority (18 of 21 ) have secretaries who help them with the preparation of the documents, and most report that they collaborate frequently with fellow subject specialists. Yet only two of the 21 work in collaboration with language specialists (translators, professional writers, documentalists or editors). They appear to act as their own language specialists: 9 of the 21 reported that they themselves sometimes translate documents.

We expected the subject specialists to report that they worked with much more highly specialized texts that the professional writers did; however, the technical documents most frequently produced by both groups are correspondence and reports. Subject specialists also report that their writing includes a large proportion of proposals, procedures, instructions, manuals, specifications, and calls for tender (see Table 1).

As for the language in which they work, the subject specialists indicated that they work mostly in French. More than two-thirds (16 out of 21) 
Table 1: Types of Technical Texts Produced

\begin{tabular}{|l|c|c|}
\cline { 2 - 3 } & $\begin{array}{l}\text { Technical } \\
\text { Writers } \\
\text { (Survey 1) }\end{array}$ & $\begin{array}{l}\text { Subject } \\
\text { Specialists } \\
\text { (Survey 2) }\end{array}$ \\
\hline Correspondence & $67 \%$ & $100 \%$ \\
\hline Technical Reports & $54 \%$ & $90 \%$ \\
\hline $\begin{array}{l}\text { Proposals, Directives, } \\
\text { Procedures }\end{array}$ & $52 \%$ & $80 \%$ \\
\hline Instructions, Manuals & $28 \%$ & $85 \%$ \\
\hline $\begin{array}{l}\text { Specifications, Calls } \\
\text { for Tender }\end{array}$ & $23 \%$ & $75 \%$ \\
\hline
\end{tabular}

conceive and write technical texts in French only. The majority use only French documentation in their work, whereas three use English documentation, seven use both English and French documentation, and one reported using Spanish documentation as well. However, it must be remembered that the number of respondents was small, they all work in Quebec, and they all work for either private enterprise or the Quebec provincial government. It is therefore impossible to make a significant comparison with the population of the first survey. What does emerge is trends: within Quebec, a large proportion of technical writing done by both language specialists and subject specialists is produced originally in French; however, translation and consultation of English-language documents play a significant role in the work of many.

In a final section of our second questionnaire, we asked the subject specialists about the role of technical writers (i.e. language specialists) in their workplace. Only five of the 21 responded that their company or organization hired the services of technical writers, and only one of these respondents indicated that the employer had a full-time technical writer on staff. However, the lack of professional language specialists does not reflect a lack of interest in hiring such specialists: 14 out of the 21 respondents confirmed that their organizations needed to hire professional writers trained to do technical writing. Although these subject specialists do their own technical writing, they indicated that they would like their employers to 
hire technical writers, either to do the writing for them or to help them with it. When we asked them about the skills they would require these technical writers to have, the profile drawn was very similar to that which emerged from the first survey: first and foremost, the specialists required a technical writer to have a good knowledge of the language, and secondly, to have the ability to write for a specific target audience. However, among this population of subject specialists, discipline-specific knowledge was rated as less important than any of the language-related skills specified in the questionnaire. These results are consistent with an observation made in a recent MacLean's article, to the effect that employers of technical writers are more interested in hiring good communicators than "computer wizards" (55).

\section{French-Language Programs in Technical Writing}

The two types of writers who were targeted in these surveys - the professional writer and the subject specialist who writes - do not have the same type of training and educational background; indeed, the types of technical writing training appropriate for the two groups are very different. Broadly speaking, there are two types of programs in French technical writing. First, there are technical writing courses offered within the framework of a subject specialty. At the college level, many of the CEGEPs (Quebec colleges) offer courses in "technical writing" to students in specialized programs. At the university level, numerous specialized programs offered by bilingual or francophone universities include courses in French writing (often described as courses in technical writing, scientific writing, or business writing), courses which often involve a review of grammar rules and an introduction to writing techniques. For example, writing courses of this type are offered by the École des Hautes Études commerciales and the École polytechnique of the Université de Montréal. Technical writing certificate programs are offered at Laval University and at the École nationale d'aéronautique of the Collège Édouard-Montpetit.

A second type of French-language writing program can be found in arts and humanities faculties in Quebec universities and in bilingual Canadian universities. Only one francophone university offers a BA program specifically in professional writing: the Université de Sherbrooke, where the BA in Études françaises, with a major in rédaction and a minor in communications, is offered within the cooperative system, allowing students to go on work terms as writers-in-training. Also available are a number of 
other university programs that, although not focused specifically on professional writing, nevertheless can lead a student into the profession: these include BA and certificate programs in communications, journalism, translation, and other fields related to professional writing.

A complete description of French-language technical writing programs remains to be done. ${ }^{2}$ The three researchers who carried out the studies described in this article are already involved in a detailed study of this issue, with a view to identifying and describing all the programs that exist in this area. The results of the investigation will be presented in a future article.

\section{Conclusion}

The two surveys that we conducted gave us insight into the practice of French-language professional writing and technical writing in Canada, and specifically in Quebec. Technical writing is done both by people we have termed "professional writers," and by people we have termed "subject specialists." In order to gain a complete overview, we conducted separate surveys on these two target groups. The results of our surveys indicated that there are similarities between the type of work both groups do: many respondents from both groups indicate that they are involved with all stages of the production process and that they produce similar types of documents. Neither group is homogeneous: respondents from both groups have diverse educational backgrounds. Thus no single profile emerges, neither that of the "professional" technical writer nor that of the specialist who writes.

Our first survey, which targeted professional writers, encompassed writers working for different types of employers in a variety of locations: we observed that the work these writers do varies significantly depending on whether they work for the federal government, the Quebec provincial government, or private enterprise. Specifically, the category of employer appears to have a strong impact on the language combinations with which the writers work, the need for them to know English, and the role translation plays in their work. Demands of the marketplace and official language policies that apply to the various workplaces no doubt help explain this observation.

French-language technical writing invites further study. Very little

2. The article "Technical Communication Programs at Canadian Post-Secondary Institutions" by Graves et al. is devoted exclusively to English-language institutions and does not describe French-language courses and programs. 
research has been conducted on technical writing in French, particularly when compared to what has been done in the field of technical writing in English. Ten years ago, Lepick Kling wrote of English-language technical writing, "As a young profession, technical writing is still in a process of selfdefinition" (472); this observation seems to be doubly applicable to the profession as practised today in French in Quebec and Canada.

\section{References}

Bossé-Andrieu, J., Cajolet-Laganière, H., \& Russell, P. (1994). La rédaction professionnelle en français au Canada. Joumal of Technical Writing and Communication, 24(3), 251-264.

Cajolet-Laganière, H., Collinge, P., \& Laganière, G. (1988). Rédaction technique et administrative (3e éd.). Sherbrooke : Éditions Laganière.

Clas, A. \& Horguelin, P. (1991). Le français, langue des affaires (3e éd.). Montreal: McGraw-Hill.

Communications: Technical writers and trainers. (1995, November 20). MacLean's, p. 55.

Graves, R., McFadden, J., \& Moore, S. (1994). Technical communication programs at Canadian post-secondary institutions. Journal of Technical Writing and Communication. 24(3), 237-250.

Harris, R. \& Russell, P. (1994). Introduction. Journal of Technical Writing and Communication. 24(3), 221-236.

Hull, D.L. (1987). Business and technical communication: A bibliography, 19751985. Metuchen, N. J \& London: The Scarecrow Press, Inc.

Kocourek. R. (1994). La langue française de la technique et de la science : vers une linguistique de la langue savante (2e éd.). Wiesbaden: Brandstetter Verlag.

Larivière, L. (1995). Situation de la rédaction professionnelle dans l'entreprise : Résultats d'une enquête effectuée, en 1992, auprès de 26 entreprises (Sociétés d'état et Sociétés commerciales publiques et privées) situées dans la région montréalaise. Technostyle 12(1), 67-98.

Larose, R. (1992). La rédaction de rapports. Structure des textes et stratégie de communication. Quebec: Presses de l'Université du Québec. 
Lepick Kling, J. (1985). The technical writing profession. In M. Moran and D. Journet, (Eds.). Research in technical communication: $A$ bibliographic sourcebook (pp. 469-479). Westport, CT: Greenwood Press.

Marret, A., Simonet, R., \& Salzer, J. (1984). Écrire pour agir. Paris: Les Éditions d'organisation.

Moran, M. G. and D. Journet (Eds). (1985). Research in technical communication: A bibliographic sourcebook. Westport, CT: Greenwood Press.

Séguinot, C. (1994). Technical writing and translation: Changing with the times. Joumal of Technical Writing and Communication, 24(3), 285-292

Timbal-Duclaux, L. (1991). L'expression écrite. Écrire pour communiquer. Paris : ESF.

\section{Appendix A: Survey 1}

\section{ENQUÊTE SUR LA RÉDACTION \\ PROFESSIONNELLE EN FRANÇAIS AU CANADA}

\section{PARTIE I: RENSEIGNEMENTS SUR LE RÉDACTEUR OU LA RÉDACTRICE}

\section{TRAVAIL DU RÉADACTEUR OU DE LA RÉDACTRICE}

Quelles sont les tâches effectuées par vos rédacteurs et rédactrices ou par vous-même? (Cochez une ou plusieurs cases et, si possible, donnez un pourcentage.)

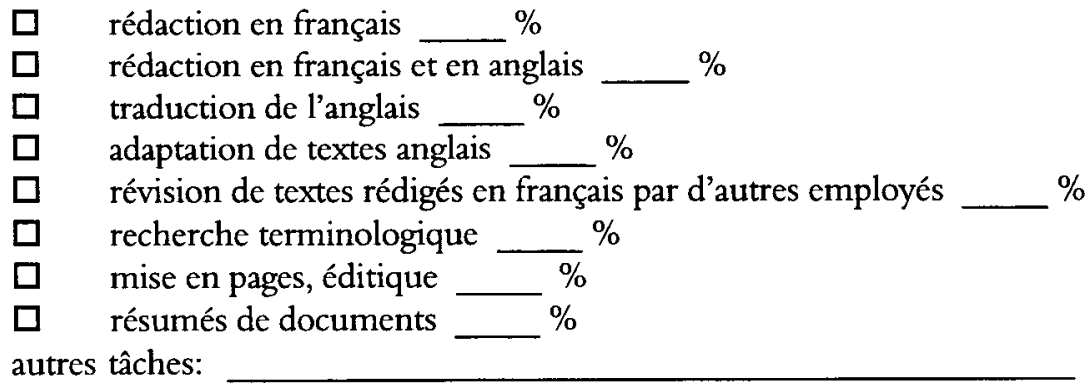


Quels sont les domaines auxquels appartiennent les textes rédigés par vos rédacteurs et rédactrices ou par vous-même?

(Cochez une ou plusieurs cases, selon le cas, et apportez, si possible, quelques précisions.)

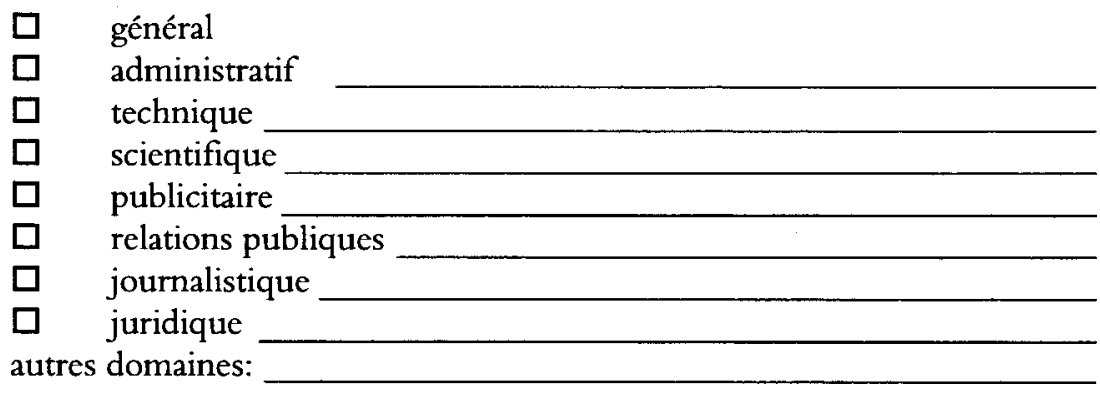

\section{RÉDACTION TECHNIQUE (à remplir le cas échéant)}

Quelles sortes de textes techniques sont rédigés par vos rédacteurs et rédactrices ou par vous-même?

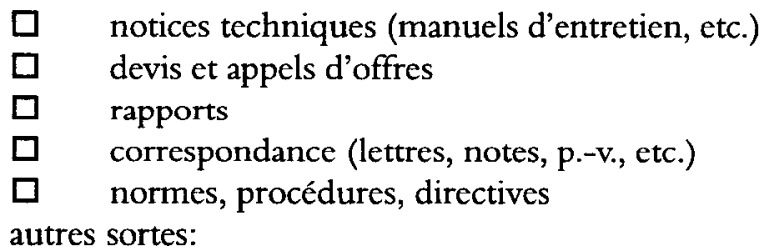

Les textes techniques préparés par vos rédacteurs et rédactrices ou par vousmême sont-ils:

- conçus et rédigés en français?

toujours $\square \quad$ le plus souvent $\square$ parfois $\square \quad$ rarement $\square$ jamais $\square$

- adaptés ou traduits de l'anglais?

toujours $\square \quad$ le plus souvent $\square \quad$ parfois $\square \quad$ rarement $\square$ jamais $\square$ 


\section{DOCUMENTATION}

Les textes rédigés par vos rédacteurs et rédactrices ou par vous-même sont-ils préparés à partir d'une documentation fournie:

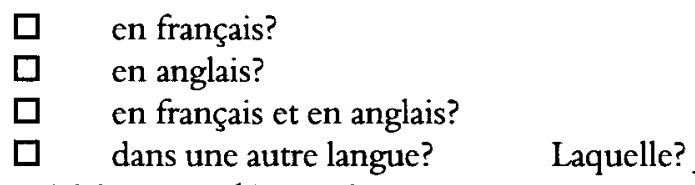

\section{SOUTIEN EN INFORMATIQUE}

Quels logiciels utilisez-vous pour la rédaction?

$\square \quad$ aucun logiciel

- traitment de texte:

$\square \quad$ WordPerfect ou Windows (IBM ou compatible)

ㅁord (Macintosh) autres logiciels:

- éditique:

$\square \quad$ PageMaker

ㅁ Framemaker

$\square \quad$ Ventura

QuarkXPress autres logiciels

- banque de données terminologiques:

ㅁ Termium (banque de terminologie du gouvernement fédéral)

$\square \quad$ BTQ (banque de terminologie de Québec) autres banques: autres aides informatiques:

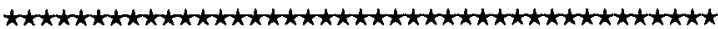


DONNÉES SUR LE RÉPONDANT OU LA RÉPONDANTE

Travaillez-vous

$\square \quad$ dans un service de gouvernement fédéral?

$\square$ dans un service du gouvernement provincial?

$\square \quad$ dans une entreprise privée?

$\square$ comme rédactrice ou rédacteur indépendant ou comme pigiste?

SI VOUS TRAVAILLEZ COMME RÉDACTRICE OU RÉDACTEUR INDÉPENDANT OU COMME PIGISTE, VOTRE COLLABORATION S'ARRÊTE ICI. NOUS VOUS REMERCIONS SINCĖREMENT DE VOTRE AIDE, ET NOUS VOUS PRIONS DE BIEN VOULOIR ENVOYER CE QUESTIONNAIRE À L'ADRESSE INDIQUÉE À LA PAGE 6.

\section{PARTIE II RENSEIGNEMENTS SUR L'EMPLOYEUR OU L'EMPLOYEUSE (VOLET À REMPLIR PAR LE OU LA «RESPONSABLE» D'UN SERVICE, D'UNE ENTREPRISE, ETC.)}

\section{IMPORTANCE DE LA RÉDACTION EN FRANÇAIS DANS VOTRE SERVICE OU ENTREPRISE}

Votre service ou entreprise s'occupe

$\square \quad$ de rédaction en français;

$\square$ de rédaction en français et en anglais;

$\square \quad$ à la fois de rédaction (en français ou en anglais) et de traduction.

Quel pourcentage du travail de rédaction et de traduction les tâches suivantes représentent-elles?

$$
\begin{array}{lllll}
10 \% & 25 \% & 50 \% & 75 \% & 100 \%
\end{array}
$$

rédaction en français

rédaction en anglais

traduction

(du français vers l'anglais)

traduction

(de l'anglais vers le français) 
Précisions sur l'importance de la rédaction en français dans votre service ou entreprise.

Nombre de personnes qui font de la rédaction en français dans votre service ou entreprise:
1 à $5 \square$
6 à 10
11 à 20
plus de $20 \square$

\section{RECRUTEMENT DU PERSONNEL}

1) Avez-vous recruté ou recrutez-vous des rédactrices ou rédacteurs professionnels?

oui $\square \quad$ non $\square$

2) Si vous recrutez des rédactrices ou rédacteurs professionnels

a) Quels diplômes exigez-vous
$\square \quad \mathrm{DEC}$
$\square \quad$ Certificat en rédaction
$\square \quad$ B.A. français/lettres françaises
$\square \quad$ B.A. rédaction (Sherbrooke)
$\square \quad$ B.A. en traduction
ㅁ autre diplôme (précisez)

b) Avez-vous des exigences supplémentaires? oui $\square$ non $\square$ Si oui, lesquelles?

c) Faites-vous passer un test aux candidats et candidates? oui $\square$ non $\square$ Si oui, en quoi consiste ce test?

3) Si vous ne recrutez pas de rédactrices ou de rédacteurs professionnels, qui est responsable de la rédaction des textes professionnels en français dans votre service ou entreprise?

$$
\text { des traducteurs ou traductrices? oui } \square \text { non } \square
$$


des gestionnaires?

oui $\square \quad$ non $\square$

d'autres employés ou employées? (veuillez préciser)

4) Offrez-vous une formation interne à vos rédacteurs et rédactrices? non $\square$

oui, formation à l'interne $\square \quad$ oui, formation à l'extérieur

Si oui, en quoi consiste cette formation?

\section{ATTENTES DE L'EMPLOYEUR OU EMPLOYEUSE}

Quelle importance accordez-vous, chez les rédacteurs et rédactrices, aux qualités et aptitudes suivantes?

$$
\text { (faible) } 1 \quad 2 \quad 3 \quad 4 \quad 5 \text { (très grande) }
$$

$\begin{array}{llllll}\text { connaissance de la langue } & \square & \square & \square & \square & \square \\ \text { connaissance du domaine } & \square & \square & \square & \square & \square \\ \text { connaissance des outils } & \square & \square & \square & \square & \square \\ \begin{array}{l}\quad \text { informatiques } \\ \text { culture générale }\end{array} & \square & \square & \square & \square & \square \\ \begin{array}{c}\text { capacité d'écrire des textes } \\ \quad \\ \text { en fonction du client }\end{array} & \square & \square & \square & \square & \square \\ \begin{array}{l}\text { capacité de travailler sous } \\ \quad\end{array} & & & & \\ \text { pression } & \square & \square & \square & \square & \square \\ \text { esprit créateur } & \square & \square & \square & \square & \square \\ \text { expression orale } & \square & \square & \square & \square & \square\end{array}$

autres qualités et aptitudes:

\section{PRÉCISIONS SUPPLÉMENTAIRES}

Êtes-vous

$\square$ responsable d'un service linguistique?

$\square$ responsable d'un groupe de rédacteurs?

$\square$ rédacteur ou rédactrice dans un service ou entreprise? autres fonctions: 
Nous vous remercions sincèrement de votre aide et nous vous prions de bien vouloir envoyer ce questionnaire à l'adresse suivante:

Madame Pamela Russell

Département des lettres et communications

Faculté des lettres et sciences humaines

Université de Sherbrooke

Sherbrooke (Québec)

J1K 2R1

\section{Appendix B: Survey 2}

\section{ENQUÊTTE SUR LA RÉDACTION TECHNIQUE EN FRANÇAIS}

\section{DONNÉES SUR LE RÉPONDANT}

\section{FONCTION DANS L'ENTREPRISE}

- Administrative (préciser)

- Technique (préciser)

TYPE D'ENTREPRISE

$\begin{array}{llll}\text { consultant } & \square & \text { université } & \square \\ \text { manufacturier } & \square & \text { société d'exploitation } & \square \\ \text { distributeur } & \square & \text { entreprise de transport } & \square \\ \text { détaillant } & \square & \text { entreprise de télécommunication } & \square \\ \text { ministère } & \square & \text { entrepreneurs en construction } & \square \\ \text { autres types (préciser) } & & \end{array}$

VOTRE FORMATION DIPLÔME SPÉCIALITÉ

- Technique Collégial

Universitaire

1er cycle

2e cycle

3e cycle

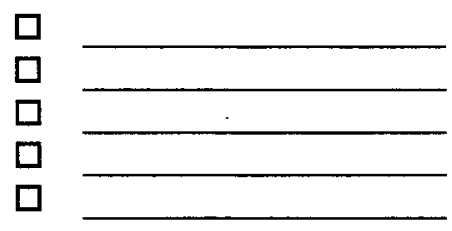


- Formation en rédaction

- autodidacte

- cours

- session

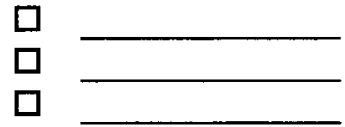

QUELS TYPES DE DOCUMENTS TECHNIQUES PRÉPAREZVOUS?

- Notes techniques Souvent $\square \quad$ Parfois $\square \quad$ Jamais $\square$

- Devis et appels d'offres

- Rapports techniques Souvent $\square \quad$ Parfois $\square \quad$ Jamais $\square$

- Correspondance Souvent $\square$ Parfois $\square \quad$ Jamais $\square$ (lettres, notes, etc.)

- Procès-verbaux Souvent $\square \quad$ Parfois $\square \quad$ Jamais $\square$

et comptes rendus

- Procédures et directives Souvent $\square$ Parfois $\square$ Jamais $\square$

- Manuels et notices Souvent $\square$ Parfois $\square$ Jamais $\square$ d'exploitation, d'entretien, de qualité, etc.

- Offres de service Souvent $\square$ Parfois $\square \quad$ Jamais $\square$ et propositions

- Brochures, dépliants Souvent $\square$ Parfois $\square \quad$ Jamais $\square$

- Rapports annuels Souvent $\square$ Parfois $\square$ Jamais $\square$ de l'entreprise

- Autres types de documents (préciser):

LES TEXTES TECHNIQUES QUE VOUS PRÉPAREZ SONT-ILS: conçus et rédigés en français?

Toujours $\square$ Le plus souvent $\square$ Rarement $\square \quad$ Jamais $\square$ conçus et rédigés en anglais?

Toujours $\square$ Le plus souvent $\square$ Rarement $\square \quad$ Jamais $\square$ adaptés ou traduits de l'anglais?

Toujours $\square$ Le plus souvent $\square$ Rarement $\square \quad$ Jamais $\square$ 
adaptés ou traduits d'une autre langue

Toujours $\square$ Le plus souvent $\square$ Rarement $\square \quad$ Jamais $\square$

Laquelle?

DANS LA PRÉPARATION DE TEXTES TECHNIQUES EN

FRANÇAIS, À QUELLES TÂCHES PARTICIPEZ-VOUS?

Étapes préparatoires

- Conception

Souvent $\square \quad$ Parfois $\square \quad$ Jamais $\square$

- Recherche documentaire

Souvent $\square \quad$ Parfois $\square \quad$ Jamais $\square$

- Recherche terminologique

Souvent $\square \quad$ Parfois $\square \quad$ Jamais $\square$

- Établissement des grandes lignes du texte

Souvent $\square \quad$ Parfois $\square \quad$ Jamais $\square$

Rédaction du document

- Premier jet

Souvent $\square \quad$ Parfois $\square \quad$ Jamais $\square$

- Révision

Souvent $\square \quad$ Parfois $\square \quad$ Jamais $\square$

Vous arrive-t-il de traduire des textes technique?

\section{Oui $\square \quad$ Non $\square$}

Si oui,

Du français à l'anglais

De l'anglais au français

Autres traductions

De à

Présentation matérielle

- Éditique

- Mise en pages

- Graphiques

$\begin{array}{lll}\text { Souvent } \square & \text { Parfois } \square & \text { Jamais } \square \\ \text { Souvent } \square & \text { Parfois } \square & \text { Jamais } \square \\ \text { Souvent } \square & \text { Parfois } \square & \text { Jamais } \square\end{array}$

Souvent $\square \quad$ Parfois $\square \quad$ Jamais $\square$

Souvent $\square \quad$ Parfois $\square \quad$ Jamais $\square$

Souvent $\square \quad$ Parfois $\square \quad$ Jamais $\square$ 
- Autres tâches (préciser) Souvent $\square \quad$ Parfois $\square \quad$ Jamais $\square$

Globalement, combien d'heures par semaine consacrez vous, en moyenne, aux activités de rédaction technique mentionnées ci-dessus? h/sem.

\section{DONNÉES SUR L'ÉQUTPE}

Travaillez-vous en collaboration avec d'autres personnes dans la préparation de vos documents techniques?

\section{Oui $\square \quad$ Non $\square$}

Si oui, avec:

- des spécialistes

Très souvent $\square \quad$ Rarement $\square \quad$ Jamais du domaine (professionnels techniques)

- des spécialistes Très souvent $\square$ Rarement $\square$ Jamais de la langue (traducteurs, rédacteurs ou réviseurs professionnels)

- secrétaires Très souvent $\square$ Rarement $\square$ Jamais

- autres personnes

Très souvent $\square$ Rarement $\square \quad$ Jamais (préciser)

Globalement, combien d'heures par semaine ces personnes consacrent-elles, en moyenne, aux activités reliées à la rédaction technique?

- spécialistes de domaine (professionnels techniques) $\mathrm{h} / \mathrm{sem}$.

- spécialistes de la langue (traducteurs, rédacteurs ou réviseurs professionnels)

- secrétaires

- autres personnes (préciser) h/sem. h/sem. h/sem.

\section{DOCUMENTATION}

Les textes rédigés par vous-même ou par les membres de votre équipe sontils préparés à partir d'une documentation fournie:

- en français?

- en anglais? 
- en français et en anglais? $\quad \square$

- dans une autre langue?

Laquelle?

Précisions supplémentaires

Avez-vous accès (vous-même ou votre équipe), à une banque de données terminologiques?

- Termium (banque de données du gouvernement fédéral) $\square$

- BTQ (banque de terminologie du Québec)

- Autres aides informatiques (préciser)

Utilisez-vous (vous-même ou votre équipe), des ouvrages de référence? Si oui, lesquels?

- Dictionnaires généraux

Souvent $\square \quad$ Parfois $\square \quad$ Jamais $\square$

- Dictionnaires spécialisés

Souvent $\square \quad$ Parfois $\square \quad$ Jamais $\square$

- Grammaires et dictionnaires

Souvent $\square \quad$ Parfois $\square \quad$ Jamais de difficultés

- Manuels de rédaction $\quad$ Souvent $\square \quad$ Parfois $\square \quad$ Jamais $\square$ technique et administrative

- Guides, manuels ou autres $\quad$ Souvent $\square \quad$ Parfois $\square \quad$ Jamais $\square$ documents de référence internes

- Lexiques et vocabulaire $\quad$ Souvent $\square \quad$ Parfois $\square \quad$ Jamais $\square$ spécialisés

- Logiciels de correction $\quad$ Souvent $\square \quad$ Parfois $\square \quad$ Jamais $\square$

- Autres documents (spécifier)

\section{DONNÉES SUR L'ENTREPRISE}

Votre entreprise embauche-t-elle des rédactrices et rédacteurs techniques?

\section{Oui $\square \quad$ Non $\square$}

Si oui, s'agit-il

- d'employés permanents $\square \quad$ Nombre

- de pigistes $\square$ Nombre 
Quels diplômes détiennent-ils?

DEC

Certificat (préciser le domaine)

Baccalauréat (préciser le domaine)

Autres diplômes (préciser)

Votre entreprise fait-elle passer un test aux rédactrices et rédacteurs qu'elle recrute?

\section{Oui $\square \quad$ Non $\square$}

Si oui, en quoi consiste ce test?

Votre entreprise offre-t-elle une formation en rédaction rechnique?

$\begin{array}{ll}\text { Non } & \square \\ \text { Oui, formation à l'interne } & \square \\ \text { Oui, formation à l'extérieur } & \end{array}$

Si oui, en quoi consiste cette formation?

Estimez-vous que certains employés et employées de votre entreprise auraient intérêt à être mieux formés en rédaction technique?

Oui $\square \quad$ Non $\square$

Si oui, préciser

Estimez-vous qu'il manque des outils de référence en français dans le domaine de la rédaction technique?

Oui $\square \quad$ Non $\square$

Si oui quels genres d'outils?

Estimez-vous que votre entreprise a besoin de rédacteurs professionnels, 
spécialistes de la rédaction technique et formés à cet effet?

\section{Oui $\square \quad$ Non $\square$}

Si oui, quelle importance accordez-vous aux qualités suivantes chez les rédacteurs techniques?

$$
\text { (faible) } \quad 1 \quad 2 \quad 3 \text { (très grande) }
$$

- Connaissance de la langue

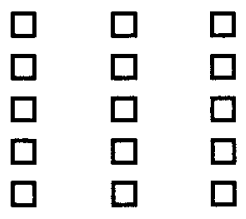

- Connaissance du domaine

- Connaissance des outils informatiques

- Culture générale

- Capacité d'écrire des textes en fonction du client

- Capacité de travailler sous pression $\quad \square \quad \square \quad \square$

- Esprit créateur

- Expression orale

Autres qualités et aptitudes:

Nous vous remercions sincèrement de votre aide et nous vous prions de bien vouloir envoyer le questionnaire à l'adresse suivante:

Hélène Cajolet-Laganière

Faculté des lettres et sciences humaines

Département des lettres et communications

Université de Sherbrooke

2500 , boul. Université

Sherbrooke (Québec) J1K 2R1 
